\title{
PENGARUH KINERJA LOGISTIK TERHADAP KINERJA OPERASIONAL PADA UKM ROTAN DI KOTA PALU
}

\author{
Ardiansyah \\ Husein Hi. Moh. Saleh \\ Suryadi Hadi \\ Prodi Manajemen, Fakultas Ekonomi, Universitas Tadulako \\ Email: ardiansyahh088@gmail.com
}

\begin{abstract}
The aim of this research is to describe the influence of logistic performance on operational performance in the rattan small-medium business in Palu. Population of this research is 24 Rattan small-medium business, which consists of 24 business owners as respondents, and 24 active employees. In total, the sample of this research is 48 people who selected with census method. Method of analysis is multiple linear regressions by using software of SPSS for Windows Release 16.0. Hypothesis test shows significance level of $\alpha=0.05$ and reliability test using the coefficient values shows cronbach alpha with coefficient of $\alpha=0,60$. The result indicates that logistic performance simultaneously have significant influence on operational performance, with adjusted $R$-square value of $46.4 \%$. Partially, with the standard of $\alpha=0.05, X 1, X 2$ and X3 have significant influence on $Y$ with sig. value of 0.033, 0.037 and 0.000 respectively. The correlation test shows a correlation coefficient by 0.706 , which means that the variable of logistic performance has a strong relationship with the operational performance of $70.6 \%$.
\end{abstract}

Keywords: logistic performance, customer service, operational metrics, logistic costs, and operational performance, rattan small-medium enterprises

\section{Abstrak}

Tujuan dari penelitian ini adalah untuk mendeskripsikan pengaruh kinerja logistik terhadap kinerja operasional pada UKM industri rotan di Kota Palu. Populasi dalam penelitian ini adalah 24 Usaha Kecil Menengah Rotan yang terdiri dari 24 pemilik usaha sebagai responden, dan 24 karyawan aktif sehingga sampel penelitian ini adalah 48 responden dengan teknik sampel yang digunakan adalah Sensus. Metode analisis yang digunakan adalah analisis regresi linier berganda dengan menggunakan perhitungan dari software SPSS for Windows Release 16,0. Uji hipotesis yang digunakan memiliki tingkat signifikansi $\alpha=0,05$ dan untuk uji reliabilitas menggunakan nilai koefisien alan croanbach dengan koefisien nilai batas $\alpha=$ $.0,60$. Hasil penelitian menunjukkan bahwa kinerja logistik secara simultan menghasilkan pengaruh yang signifikan terhadap kinerja operasional, dengan nilai Adjust R-square sebesar $46,4 \%$. Secara parsial dengan standar $\alpha=0,05$ hasil penelitian X1, X2 dan X3 berpengaruh signifikan terhadap Y dengan sig masing-masing yaitu 0,033, 0,037 dan 0,000. Hasil korelasi tersebut menunjukkan koefisien korelasi sebesar 0,706 yang berarti bahwa variabel kinerja logistik memiliki hubungan yang kuat dengan kinerja operasional sebesar 70,6\%.

Kata Kunci: Kinerja Logistik, Layanan Pelanggan, Metrik Operasional, Biaya Logistik, dan Kinerja Operasional, Usaha Kecil dan Menengah Rotan

\section{PENDAHULUAN}

\section{Latar Belakang Penelitian}

Tantangan perusahaan manufaktur di era kompetitif dewasa ini semakin meningkat. Tingkat persaingan bisnis yang sangat ketat menyebabkan setiap usaha harus menerapkan strategi yang tepat, guna memenangkan persaingan bisnis tersebut. Salah satu strategi bisnis yang dapat di lakukan untuk memperkecil dampak dari meningkatnya tingkat persaingan bisnis dengan melalui peningkatkan kinerja logistik. Melihat pesatnya pertumbuhan ekonomi disegala bidang membuat persaingan antar perusahaan yang berperan dalam aktivitas ekonomi akan semakin tinggi. Menjawab tantangan 
tersebut, dibutuhkan langkah strategis dari perusahaan dengan proses pengadaan barang atau jasa pada saat yang dibutuhkan secara efektif dan efisien pada kegiatan perusahaan.

Pada umumnya konsumen menginginkan agar dapat memperoleh produk pada level harga yang dapat dijangkau. Keinginan konsumen ini dilakukan secara optimal dengan menggunakan seluruh kemampuan yang ada dengan tujuan akhir yaitu memberikan nilai tambah kepada konsumen. Untuk mewujudkan hal tersebut, maka peran logistik harus lebih dioptimalkan (Chandra, 2013).

Hubungan antara kinerja logistik dan kinerja operasional perusahaan sangat positif dan mendapatkan banyak mendapat perhatian dari akademisi. Anderson, dkk. (1997) mengemukakan bahwa kinerja logistik yang baik dapat menurunkan biaya, meningkatkan pendapatan dan efisiensi serta efektivitas dari aset usaha yang digunakan. Kinerja logistik yang baik dapat membantu perusahaan dalam mempertahankan hubungannya dengan pelanggan melalui pengurangan siklus waktu yang dibutuhkan (Lambert \& Pohlen, 2001). Penelitian lain yang mendukung hubungan antara kinerja logistik dan kinerja operasional menyimpulkan bahwa biaya logistik dan kualitas sangat besar pengaruhnya terhadap perusahaan retail (Schramm-Klein \& Morschett, 2006). Sementara itu, penelitian Shang \& Marlow (2005) menyimpulkan bahwa kinerja operasional perusahaan manufaktur di Taiwan meningkat disebabkan oleh peningkatan kinerja logistik. Jadi, perusahaan dapat memperoleh manfaat yang besar dari peningkatan kinerja logistik yang baik.

Agar industri rotan memiliki keunggulan kompetitif dan dapat berkelanjutan, maka pengembangannya perlu dilakukan melalui pendekatan pasar. Salah satu upaya pendekatan pasar yang harus dilakukan adalah meningkatkan konsumsi lokal, dengan memperkenalkan produk dari aspek budaya sehingga produk lokal yang di hasilkan tidak kalah bersaing dan tidak tersingkirkan dengan produk-produk impor dari luar negeri.

\section{Permasalahan Penelitian}

Berdasarkan latar belakang di atas, dapat di identifikasikan masalah sebagai berikut:

1. Apakah variabel kinerja logistik yang terdiri dari (layanan konsumen, metrik operasional, dan biaya logistik) secara simultan berpengaruh signifikan terhadap kinerja operasional UKM industri rotan di Kota Palu?

2. Apakah layanan konsumen secara parsial berpengaruh signifikan terhadap kinerja operasional UKM industri rotan di Kota Palu?

3. Apakah metrik operasional secara parsial berpengaruh signifikan terhadap kinerja operasional UKM industri rotan di Kota Palu?

4. Apakah biaya logistik secara parsial berpengaruh signifikan terhadap kinerja operasional UKM industri rotan di Kota Palu?

\section{Tujuan Penelitian}

Adapun tujuan penelitian yang ingin dicapai adalah:

1. Untuk mengetahui pengaruh simultan variabel kinerja logitik yang terdiri dari layanan konsumen, metrik operasional dan biaya logistik terhadap Kinerja Operasional UKM industri rotan di Kota Palu.

2. Untuk mengetahui pengaruh parsial variabel layanan konsumen terhadap kinerja operasional UKM industri rotan di Kota Palu.

3. Untuk mengetahui pengaruh parsial variabel metrik operasional terhadap kinerja operasional UKM industri rotan di Kota Palu.

4. Untuk mengetahui pengaruh parsial variabel biaya logistik terhadap kinerja operasional UKM industri rotan di Kota Palu.

\section{KAJIAN LITERATUR DAN PENGEMBANGAN HIPOTESIS}

\section{Usaha Mikro Kecil dan Menengah (UMKM)}

Usaha Mikro, Kecil, dan Menengah merupakan kegiatan usaha yang mampu memperluas lapangan kerja dan memberikan pelayanan ekonomi secara luas kepada masyarakat, dan dapat berperan dalam proses pemerataan dan peningkatan pendapatan masyarakat, mendorong pertumbuhan ekonomi, dan berperan dalam mewujudkan stabilitas nasional. 


\section{Supply Chain Management (SCM)}

SCM merupakan sebuah pendekatan yang digunakan secara efisien untuk mengintegrasikan pemasok, pabrik, gudang, dan toko-toko sehingga produk diproduksi dan didistribusikan dalam jumlah, lokasi dan waktu yang tepat, serta dalamm rangka pemenuhan pesanan dengan meminimalkan lebarnya sistem dan biaya yang bertujuan menciptakan kepuasan pelanggan sesuai dengan tingkat tuntunan pelayanan (Simchi-Levi \& Kaminsky, 2003).

\section{Manajemen Logistik}

Menurut Siagian (2005), manajemen logistik mengutamakan pengelolaan, termasuk arus barang dalam perusahaan dan orientasi pada perencaanaan dan kerangka kerja yang menghasilkan rencana tunggal arus barang dan informasi di perusahaan sedangkan supply chain management mengutamakan arus barang antar perusahaan, mulai dari awal kegiatan sampai produk akhir, orientasinya atas dasar kerja sama dan mengusahakan hubungan serta koordinasi antar proses dari perusahaan mitra guna menunjang kegiatan proses sampai ke tangan konsumen.

\section{METODE PENELITIAN}

\section{Metode Pengumpulan Data}

Data-data dalam penelitian ini diperoleh dengan menggunakan beberapa metode pengumpulan data sebagai berikut:

1. Observasi merupakan proses untuk memperoleh data dari tangan pertama dengan mengamati orang dan tempat pada saat dilakukan penelitian (Creswell, 2012).

2. Kuesioner merupakan teknik pengumpulan datayang dilakukan dengan cara memberi separangkat pertanyaan atau pernyataan tertulis kepada responden untuk dijawabnya. Kuesioner merupakan teknik pengumpulan data yang efisien bila peneliti tahu apa yang bisa diharapkan dari responden. Kuesioner dapat berupa pertanyaan/pernyataan tertutup atau terbuka, dapat diberikan kepada responden secara langsung atau dikirim melalui pos atau internet.

\section{Populasi dan Sampel Penelitian}

Populasi dalam penelitian ini adalah UKM industri rotan di Kota Palu. Yaitu sebesar 29 UKM industri rotan, sehingga sampel dari penelitian ini adalah seluruh UKM industri rotan yang ada di Kota Palu.

\section{Variabel Penelitian}

Variabel-variabel yang dipakai dalam penelitian ini, yaitu variabel dependen (variabel terikat) merupakan variabel yang dipengaruhi atau yang menjadi akibat karena adanya variabel bebas.

\section{Metode Analisis Data}

\section{Uji instrument pengumpulan data}

\section{Uji Validitas}

Menurut Ghozali (2006) uji validitas digunakan untuk mengukur sah atau valid tidaknya suatu kuesioner. Validitas suatu istrumen berkaitan dengan kemampuan instrumen itu untuk mengukur atau menangkap karakteristik dari variabel yang dimaksudkan untuk diukur.

\section{Uji Reliabilitas}

Menurut Ghozali (2006) reliabilitas adalah alat untuk mengukur suatu kuesioner yang merupakan indikator dari variabel atau konstruk. Uji reliabilitas pada penelitian ini di ukur dengan cara One Shot atau pengukuran sekali saja. Disini pengukurannya hanya sekali dan kemudian hasilnya dibandingkan dengan pertanyaan lain atau mengukur korelasi antar jawaban pertanyaan.

\section{Uji Asumsi Klasik}

\section{Uji Multikolonieritas}

Uji multikolonieritas bertujuan untuk menguji apakah model regresi ditemukan adanya kolerasi antar variabel bebas (independen). 


\section{Uji Heteroskedastisitas}

Uji heteroskedastisitas bertujuan menguji apakah dalam model regresi terjadi ketidaksamaan varians dari residual satu pengamatan ke pengamatan yang lain.

\section{Uji Normalitas}

Uji normalitas bertujuan untuk menguji apakah dalam model regresi, variabel pengganggu atau residual memiliki distribusi normal.

\section{Analisis Regresi Linear Berganda}

Analisis regresi linear berganda adalah hubungan secara linear antara dua atau lebih variabel independen $\left(\mathrm{X}_{1}, \mathrm{X}_{2}, \ldots . \mathrm{X}_{\mathrm{n}}\right)$ dengan variabel dependen atau terikat $(\mathrm{Y})$.

$$
\mathrm{Y}=\alpha+\mathrm{b}_{1} \mathrm{X}_{1}+\mathrm{b}_{2} \mathrm{X}_{2}+\mathrm{b} 3 \mathrm{X}_{3}+\mathrm{e}
$$

dimana : $\mathrm{Y}=$ Kinerja Operasional; $\alpha=$ Konstanta; $\mathrm{X}_{1}=$ Layanan Konsumen; $\mathrm{X}_{2}=$ Metrik Operasional; $\mathrm{X}_{3}=$ Biaya Logistik; $\mathrm{b}_{1}=$ Koefisien regresi variabel Layanan Konsumen; $\mathrm{b}_{2}=$ Koefisien regresi variabel Metrik Operasional; $b_{3}=$ Koefisien regresi variabel Biaya Logistik; $\mathrm{e}=$ Standard Error

\section{Uji Goodness of Fit}

Menurut Ghozali (2006) mengemukakan bahwa uji goodness of fit dapat digunakan untuk menguji apakah terdapat perbedaan signifikan antara jumlah objek atau responden yang dioberservasi yang jatuh pada setiap kategori dan jumlah objek yang diharapkan (expected) berdasarkan pada hipotesis nol.

\section{Uji Signifikansi Simultan (Uji Statistik F)}

Uji statistik F pada dasarnya menunjukkan apakah semua variabel independen atau bebas mempunyai pengaruh secara bersama-sama terhadap variabel dependen/terikat, dengan $\alpha=0,05$.

\section{Uji Signifikansi Parameter Individual (Uji Statistik t)}

Gujarati dalam Pangestu menjelasakan bahwa uji signifikansi (Uji t) merupakan prosedur yang digunakan untuk menguji kebenaran atau kesalahan dari hasil hipotesis nol dari sampel.

Dalam penelitian ini, peneliti menggunakan uji t melalui probabilitas dengan penjelasan sebagai berikut:

$$
\begin{gathered}
\text { thitung }=\frac{\mathrm{b} 1}{\mathrm{SE}(\mathrm{b} 1)} \\
\text { dimana }: \beta 1 \quad=\text { Nilai Koefisien Regresi; SE }=\text { Nilai Standar Error dari } \beta 1
\end{gathered}
$$

\section{Koefisien Determinasi $\left(R^{2}\right)$}

Uji $\mathrm{R}^{2}$ atau uji determinasi merupakan suatu ukuran yang penting dalam regresi, karena dapat menginformasikan dengan biak atau tidaknya model regresi determinasi, atau dengan kata lain angka tersebut dapat mengukur seberapa dekatkah garis regresi yang terestimasi dengan data sesungguhnya.

\section{HASIL DAN PEMBAHASAN \\ Hasil Penelitian \\ Deskripsi Karakteristik Responden}

Kuesioner penelitian ini disebar kepada 24 UKM industri rotan yang ada di Kota Palu dengan sasaran penelitian adalah 24 orang pemilik usaha dan 24 orang karyawan pada industri-industri tersebut. Jangka waktu pengambilan kuesioner bervariasi, paling cepat 1 minggu dan paling lama 1 bulan tergantung dari izin pimpinan industri tersebut. Berikut akan dijelaskan karakteristik karyawan berdasarkan jenis kelamin dan tahun berdirinya UKM industri rotan di Kota Palu. 


\section{Karakteristik Responden Berdasarkan Jenis Kelamin}

Dari hasil penelitian yang di lakukan kepada 24 orang pemilik usaha dan 24 orang karyawan pada industri rotan yang ada di Kota Palu, diketahui bahwa jenis kelamin pria dan wanita adalah sebagai berikut:

Tabel 1. Karakteristik Responden Berdasarkan Jenis Kelamin

\begin{tabular}{llcccc}
\hline & & Responden & Persen (\%) & Valid Persen & $\begin{array}{c}\text { Kumulatif } \\
\text { Persen }\end{array}$ \\
\hline Valid & Laki-Laki & 44 & 91.7 & 91.7 & 91.7 \\
& Perempuan & 4 & 8.3 & 8.3 & 100.0 \\
& Total & 48 & 100.0 & 100.0 & \\
\hline
\end{tabular}

Berdasarkan Tabel 1 di atas, terlihat bahwa responden berjenis kelamin laki-laki berjumlah 44 orang dengan persen sebesar $91,7 \%$ sedangkan jumlah responden yang berjenis kelamin perempuan sebanyak 4 orang dengan persen $8,3 \%$. Dengan demikian dapat diketahui bahwa jumlah responden yang bekerja pada UKM industri rotan tempat penelitian memiliki jumlah responden laki-laki lebih banyak jika dibandingkan dengan jumlah responden perempuan dikarenakan kondisi pekerjaan yang begitu berat sehingga dapat ketahui jumlah pekerja yang mendominasi adalah responden laki-laki.

\section{Karakteristik Responden Berdasarkan Tahun Berdirinya Usaha}

Dari hasil penelitian yang dilakukan pada industri rotan yang ada di Kota Palu, ada yang telah lama beroperasi di Kota Palu dan ada yang belum lama beroperasi. Hal tersebut dapat dikatahui dari tahun berdirinya usaha tersebut. Berikut adalah karakteristik industri rotan berdasarkan tahun berdirinya industri tersebut:

Tabel 2. Karakteristik Responden Berdasarkan Tahun Berdiri Usaha

\begin{tabular}{ccc}
\hline Tahun Berdiri & Responden & Persen (\%) \\
\hline $1970-1980$ & 4 & $8,3 \%$ \\
$1981-1990$ & 10 & $20,8 \%$ \\
$1991-2000$ & 2 & $4,2 \%$ \\
$2001-2010$ & 10 & $20,8 \%$ \\
$>2011$ & 22 & $45,8 \%$ \\
\hline Total & $\mathbf{4 8}$ & $\mathbf{1 0 0 \%}$ \\
\hline
\end{tabular}

Dari pemaparan Tabel 2 di atas, dapat di lihat bahwa UKM industri rotan yang berada di Kota Palu Mengalami penambahan usaha setiap tahunnya. Pada tahun 1970-1980 UKM industri rotan yang ada di Kota Palu baru berjumlah 4 industri dengan nilai sebesar 8,3\%. Selanjutnya pada tahun 19811990 UKM industri rotan mengalami penambahan sebanyak 10 industri dengan nilai sebesar 20,8\%. Hal ini menyatakan bahwa indusri rotan yang bermunculan di Kota Palu mengalami peningkatan sebesar 12,5\%. Selanjutnya pada tahun 1991-2000 UKM industri rotan mengalami penambahan sebanyak 2 industri dengan nilai sebesar 4,2\%. Yang menjadi kendala dalam kegiatan ekonomi rotan adalah penduduk lokal Kota Palu yang kurang menyukai peralatan berbahan rotan. Tetapi, kendala itu dapat di atasi karena, produk rotan dari Kota Palu masih diminati pasar nasional.

\section{Persentasi Variabel Penelitian}

\section{Persentasi Karakteristik Jawaban Variabel Layanan Konsumen $\left(X_{I}\right)$}

Karakteristik variabel layanan konsumen merupakan dimensi yang paling penting yang ditawarkan oleh perusahaan kepada konsumen. Berikut adalah hasil jawaban yang diberikan industri kerajinan rotan dalam layanan konsumen. 
Tabel 3. Persentasi Jawaban Responden Terhadap Layanan Konsumen $\left(\mathrm{X}_{1}\right)$

\begin{tabular}{|c|c|c|c|c|c|c|c|c|c|c|c|c|}
\hline \multirow{3}{*}{ Indikator } & \multicolumn{10}{|c|}{ Jawaban Responden } & \multirow{3}{*}{$\begin{array}{l}\text { Total } \\
\text { Skor }\end{array}$} & \multirow{3}{*}{ Mean } \\
\hline & \multicolumn{2}{|c|}{5} & \multicolumn{2}{|c|}{4} & \multicolumn{2}{|c|}{3} & \multicolumn{2}{|c|}{2} & \multicolumn{2}{|c|}{1} & & \\
\hline & $\sum$ & $\%$ & $\sum$ & $\%$ & $\sum$ & $\%$ & $\sum$ & $\%$ & $\sum$ & $\%$ & & \\
\hline $\begin{array}{l}\text { Jangka waktu } \\
\text { pemesanan }\end{array}$ & 7 & 14,6 & 30 & 62,5 & 11 & 22,9 & - & - & - & - & 188 & 3,92 \\
\hline $\begin{array}{l}\text { Konsistensi } \\
\text { pengiriman }\end{array}$ & 17 & 35,4 & 26 & 54,2 & 4 & 8,3 & 1 & 2,1 & - & - & 203 & 4,23 \\
\hline $\begin{array}{l}\text { Frekuensi } \\
\text { pengiriman }\end{array}$ & 11 & 22,9 & 14 & 29,2 & 22 & 45,8 & 1 & 2,1 & - & - & 179 & 3,73 \\
\hline Penyediaan stok & 15 & 31,2 & 24 & 50,0 & 9 & 18,8 & - & - & - & - & 198 & 4,13 \\
\hline Pelayanan fasilitas & 15 & 31,2 & 22 & 45,8 & 4 & 8,3 & 7 & 14,6 & - & - & 189 & 3,94 \\
\hline $\begin{array}{l}\text { Ketersediaan bahan } \\
\text { baku }\end{array}$ & 24 & 50,0 & 20 & 41,7 & 4 & 8,3 & - & - & - & - & 212 & 4,42 \\
\hline Layanan pendukung & 11 & 22,9 & 30 & 62,5 & 6 & 12,5 & 1 & 2,1 & - & - & 195 & 4,06 \\
\hline $\begin{array}{l}\text { Bongkar muat yang } \\
\text { baik }\end{array}$ & 22 & 45,8 & 19 & 39,6 & 3 & 6,2 & 3 & 6,2 & 1 & 2,1 & 202 & 4,21 \\
\hline \multicolumn{12}{|c|}{ Rata-Rata } & 4,08 \\
\hline
\end{tabular}

Berdasarkan data di atas, dimensi layanan konsumen untuk indikator $\mathrm{X}_{1.6}$ memiliki mean tertinggi dari yang lain yaitu sebesar 4,42 karena layanan pendukung (service support) seperti hari-hari besar keagamaan para supplier selalu menyediakan stok bahan baku sehingga para pemilik usaha mau memesan bahan baku tidak menunggu waktu yang lama. Selanjutnya dimensi layanan konsumen untuk indikator $\mathrm{X}_{1.3}$ memiliki mean terendah dari yang lain yaitu sebesar 3,73 karena frekuensi pengiriman (delivery frequency) untuk hari-hari biasa, supplier mengirimkan bahan baku ke industri kerajinan rotan membutuhkan rentang waktu yang lama karena menunggu terpenuhinya bahan baku yang dipesan kemudian bisa dikirimkan ke industri tersebut.

Persentasi Karakteristik Jawaban Variabel Metrik Operasional $\left(\mathrm{X}_{2}\right)$

Metrik operasional merupakan kegiatan operasional yang dilakukan oleh industri rotan yang berkaitan dengan kinerja logistik. Berikut disajikan Tabel jawaban responden terhadap metrik operasional pada industri rotan.

Tabel 4. Persentasi Jawaban Responden Terhadap Metrik Operasional $\left(\mathrm{X}_{2}\right)$

\begin{tabular}{|c|c|c|c|c|c|c|c|c|c|c|c|c|}
\hline \multirow{3}{*}{ Indikator } & \multicolumn{10}{|c|}{ Jawaban Responden } & \multirow{3}{*}{$\begin{array}{l}\text { Total } \\
\text { Skor }\end{array}$} & \multirow{3}{*}{ Mean } \\
\hline & \multicolumn{2}{|c|}{5} & \multicolumn{2}{|c|}{4} & \multicolumn{2}{|c|}{3} & \multicolumn{2}{|c|}{2} & \multicolumn{2}{|c|}{1} & & \\
\hline & $\sum$ & $\%$ & $\sum$ & $\%$ & $\sum$ & $\%$ & $\sum$ & $\%$ & $\sum$ & $\%$ & & \\
\hline $\begin{array}{l}\text { Jumlah barang yang } \\
\text { disimpan }\end{array}$ & 23 & 47,9 & 18 & 37,5 & 7 & 14,6 & - & - & - & - & 208 & 4,33 \\
\hline $\begin{array}{l}\text { Pemeliharaan stok } \\
\text { barang }\end{array}$ & 11 & 22,9 & 11 & 22,9 & 17 & 35,4 & 9 & 18,8 & - & - & 168 & 3,50 \\
\hline $\begin{array}{l}\text { Ketetapan dalam } \\
\text { pemesanan barang }\end{array}$ & 11 & 22,9 & 19 & 39,6 & 10 & 20,8 & 8 & 16,7 & - & - & 177 & 3,69 \\
\hline $\begin{array}{l}\text { Ketersediaan } \\
\text { transportasi }\end{array}$ & 10 & 20,8 & 12 & 25,0 & 11 & 22,9 & 15 & 31,2 & - & - & 161 & 3,35 \\
\hline $\begin{array}{l}\text { Lokasi perusahaan } \\
\text { yang strategis }\end{array}$ & 14 & 29,2 & 17 & 35,4 & 10 & 20,8 & 7 & 14,6 & - & - & 182 & 3,79 \\
\hline Ketersediaan gudang & 34 & 70,8 & 11 & 22,9 & 2 & 4,2 & 1 & 2,1 & - & - & 222 & 4,63 \\
\hline Lokasi fasilitas & 17 & 35,4 & 14 & 29,9 & 17 & 35,4 & - & - & - & - & 192 & 4,00 \\
\hline
\end{tabular}


pergudangan

\begin{tabular}{llllllllllllll} 
Tata letak gudang & 25 & 52,1 & 14 & 29,2 & 8 & 16,7 & 1 & 2,1 & - & - & 207 & 4,31 \\
Kepemilikan gudang & 24 & 50,0 & 19 & 39,6 & 5 & 10,4 & - & - & - & - & 211 & 4,40 \\
\hline \multicolumn{1}{c}{ Rata-Rata } &
\end{tabular}

Tabel 4 di atas menunjukkan bahwa indikator $\mathrm{X}_{2.6}$ memiliki nilai mean yang paling tinggi yaitu sebesar 4,63 karena ketersediaan gudang (warehouse) yang memadai dapat membantu ketersediaan bahan baku apabila diperlukan segera dan ketersediaan barang jadi di tempat usaha. Selanjutnya dimensi metrik operasional untuk indikator $\mathrm{X}_{2.4}$ memiliki mean terendah dari yang lain yaitu sebesar 3,35, karena ketidaktersediaan transportasi yang memadai dapat mempengaruhi ketepatan waktu pengiriman barang jadi maupun bahan baku dari supplier ke tempat usaha menjadi terhambat. Oleh karena itu transportasi sangat dibutuhkan dalam dunia usaha.

Cara memperoleh nilai mean dari deskripsi karakteristik jawaban responden variabel metrik operasional $\left(\mathrm{X}_{2}\right)$ adalah dengan cara menggunakan microsoft office excel yaitu nilai sigma $\left(\sum\right)$ dikalikan dengan nilai persen (\%). kemudian dijumlahkan sehingga memperoleh nilai total skor. Selanjutnya nilai total skor di bahagi dengan responden penelitian yaitu sebanyak 48 responden sehingga dapat diperoleh nilai mean tertinggi dan terendah dari karakteristik jawaban responden tersebut.

\section{Persentasi Karakteristik Jawaban Variabel Biaya Logistik $\left(X_{3}\right)$}

Biaya logistik memiliki peran yang paling besar dalam menunjang kinerja opearsional perusahaan, oleh karena itu biaya tersebut harus dikelola semaksimal mungkin agar tidak terjadi kerugian bagi sebuah perusahaan. Berikut adalah Tabel jawaban responden terhadap biaya logistik pada industri rotan.

Tabel 5. Persentasi Jawaban Responden Terhadap Biaya Logistik $\left(\mathrm{X}_{3}\right)$

\begin{tabular}{|c|c|c|c|c|c|c|c|c|c|c|c|c|}
\hline \multirow{3}{*}{ Indikator } & \multicolumn{10}{|c|}{ Jawaban Responden } & \multirow{3}{*}{$\begin{array}{l}\text { Total } \\
\text { Skor }\end{array}$} & \multirow{3}{*}{ Mean } \\
\hline & \multicolumn{2}{|c|}{5} & \multicolumn{2}{|c|}{4} & \multicolumn{2}{|c|}{3} & \multicolumn{2}{|c|}{2} & \multicolumn{2}{|c|}{1} & & \\
\hline & $\sum$ & $\%$ & $\sum$ & $\%$ & $\sum$ & $\%$ & $\sum$ & $\%$ & $\sum$ & $\%$ & & \\
\hline Biaya pemesanan & 21 & 43,8 & 22 & 45,8 & 5 & 10,4 & - & - & - & - & 208 & 4,33 \\
\hline $\begin{array}{l}\text { Biaya pemeliharaan } \\
\text { barang }\end{array}$ & 12 & 25,0 & 26 & 54,2 & 10 & 20,8 & - & - & - & - & 194 & 4,04 \\
\hline $\begin{array}{l}\text { Biaya pengadaan } \\
\text { fasilitas gudang }\end{array}$ & 6 & 12,5 & 18 & 37,5 & 10 & 20,8 & 14 & 29,2 & - & - & 160 & 3,33 \\
\hline Biaya pengemasan & 25 & 52,1 & 20 & 41,7 & 3 & 6,2 & - & - & - & - & 214 & 4,46 \\
\hline Biaya penyimpanan & 18 & 37,5 & 19 & 39,6 & 10 & 20,8 & 1 & 2,1 & - & - & 198 & 4,13 \\
\hline $\begin{array}{l}\text { Biaya kerusakan } \\
\text { barang }\end{array}$ & 24 & 50,0 & 19 & 39,6 & 5 & 10,4 & - & - & - & - & 211 & 4,40 \\
\hline Biaya pengiriman & 35 & 72,9 & 12 & 25,0 & - & - & 1 & 2,1 & - & - & 225 & 4,69 \\
\hline $\begin{array}{l}\text { Biaya sewa } \\
\text { transportasi }\end{array}$ & 26 & 54,2 & 16 & 33,3 & 4 & 8,3 & 2 & 4,2 & - & - & 210 & 4,38 \\
\hline Biaya perantara & 40 & 83,3 & 7 & 14,6 & 1 & 2,1 & - & - & - & - & 231 & 4,81 \\
\hline & & & & Rata- & ata & & & & & & & 4,28 \\
\hline
\end{tabular}

Melihat data di atas, dapat diketahui mean tertinggi dimiliki oleh $\mathrm{X}_{3.9}$ dengan nilai mean sebesar 4,81, karena biaya transportasi yang cukup tinggi akan mempengaruhi kinerja sebuah industri. Apabila biaya yang dikeluarkan semakin tinggi maka pendapatan akan berkurang sebaliknya apabila 
biaya yang dikeluarkan semakin rendah maka pendapatan akan bertambah. Selanjutnya dimensi biaya logistik untuk indikator $\mathrm{X}_{3.3}$ memiliki mean terendah dari yang lain yaitu sebesar 3,33, karena biaya pengadaan fasilitas gudang yang dikeluarkan cukup besar akan berpengaruh terhadap tingkat pendapatan dari sebuah usaha, apabila menanmbah gudang otomatis pemilik usaha akan mengeluarkan biaya yang tidak sedikit, bila biaya yang dikeluarkan seminim mungkin akan berpengaruh pada pendapatan dari sebuah usaha tersebut, karena biaya yang digunakan untuk fasilitas gudang tidak begitu besar.

Cara memperoleh nilai mean dari deskripsi karakteristik jawaban responden variabel biaya logistik $\left(\mathrm{X}_{3}\right)$ adalah dengan cara menggunakan microsoft office excel yaitu nilai sigma $(\Sigma)$ dikalikan dengan nilai persen $(\%)$. kemudian dijumlahkan sehingga memperoleh nilai total skor. Selanjutnya nilai total skor di bahagi dengan responden penelitian yaitu sebanyak 48 responden sehingga dapat diperoleh nilai mean tertinggi dan terendah dari karakteristik jawaban responden tersebut.

\section{Persentasi Karakteristik Jawaban Variabel Kinerja Operasional (Y)}

Kinerja operasional merupakan suatu pencapaian untuk mengukur produk yang dihasilkan sesuai dengan produk yang direncanakan. Berikut disajikan jawaban responden terhadap indikatorindikator pada kinerja operasional industri rotan.

Tabel 6. Persentasi Jawaban Responden Terhadap Kinerja Operasional (Y)

\begin{tabular}{|c|c|c|c|c|c|c|c|c|c|c|c|c|}
\hline \multirow{3}{*}{ Indikator } & \multicolumn{10}{|c|}{ Jawaban Responden } & \multirow{3}{*}{$\begin{array}{l}\text { Total } \\
\text { Skor }\end{array}$} & \multirow{3}{*}{ Mean } \\
\hline & \multicolumn{2}{|c|}{5} & \multicolumn{2}{|c|}{4} & \multicolumn{2}{|c|}{3} & \multicolumn{2}{|c|}{2} & \multicolumn{2}{|c|}{1} & & \\
\hline & $\sum$ & $\%$ & $\sum$ & $\%$ & $\sum$ & $\%$ & $\sum$ & $\%$ & $\sum$ & $\%$ & & \\
\hline Biaya & 15 & 31,2 & 24 & 50,0 & 9 & 18,8 & - & - & - & - & 198 & 4,13 \\
\hline Kualitas & 22 & 45,8 & 18 & 37,5 & 7 & 14,6 & 1 & 2,1 & - & & 205 & 4,27 \\
\hline Fleksibilitas & 27 & 56,2 & 20 & 41,7 & - & - & 1 & 2,1 & - & - & 217 & 4,52 \\
\hline Pengiriman & 25 & 52,1 & 21 & 43,8 & 1 & 2,1 & 1 & 2,1 & - & - & 214 & 4,46 \\
\hline Layanan & 27 & 56,2 & 19 & 39,6 & 2 & 4,2 & - & - & - & - & 217 & 4,52 \\
\hline \multicolumn{12}{|c|}{ Rata-Rata } & 4,38 \\
\hline
\end{tabular}

Dari pemaparan di atas, dapat dilihat bahwa nilai mean tertinggi adalah indikator $\mathrm{Y}_{1.3}$ dengan nilai mean sebesar 4,52 dan $Y_{1.5}$ dengan nilai mean 4,52, karena fleksibilitas layanan transportasi yang industri rotan gunakan dapat menjamin ketersediaan bahan baku artinya setiap kali memesan bahan baku maka langsung di ambil di tempat supplier dan pelayanan baik dari supplier akan mempengaruhi kelancaran operasional industri kerajinan rotan tesebut. Selanjutnya indikator kinerja operasional $Y_{1.1}$ memiliki mean terendah dari yang lain yaitu sebesar 4,13, karena biaya yang dikeluarkan oleh industri rotan untuk memelihara barang yang ada di dalam gudang dapat mempengaruhi kinerja operasional.

Cara memperoleh nilai mean dari deskripsi karakteristik jawaban responden variabel kinerja operasional (Y) adalah dengan cara menggunakan microsoft office exel yaitu nilai sigma $\left(\sum\right)$ dikalikan dengan nilai persen (\%). kemudian dijumlahkan sehingga memperoleh nilai total skor. Selanjutnya nilai total skor di bahagi dengan responden penelitian yaitu sebanyak 48 responden sehingga dapat diperoleh nilai mean tertinggi dan terendah dari karakteristik jawaban responden tersebut.

\section{Hasil Analisis Regresi Linear Berganda}

Analisis ini digunakan untuk mengetahui seberapa besar pengaruh variabel independen $(X)$ terhadap variabel dependen (Y). Dalam penelitian ini, akan di analisis berapa besar pengaruh variabel $\mathrm{X}$ yaitu Layanan Konsumen $\left(\mathrm{X}_{1}\right)$, Metrik Operasional $\left(\mathrm{X}_{2}\right)$, dan Biaya Logistik $\left(\mathrm{X}_{3}\right)$ terhadap Variabel Y yaitu kinerja Operasional. Berikut hasil analisis regresi linear berdasarkan hasil olah data SPSS. 


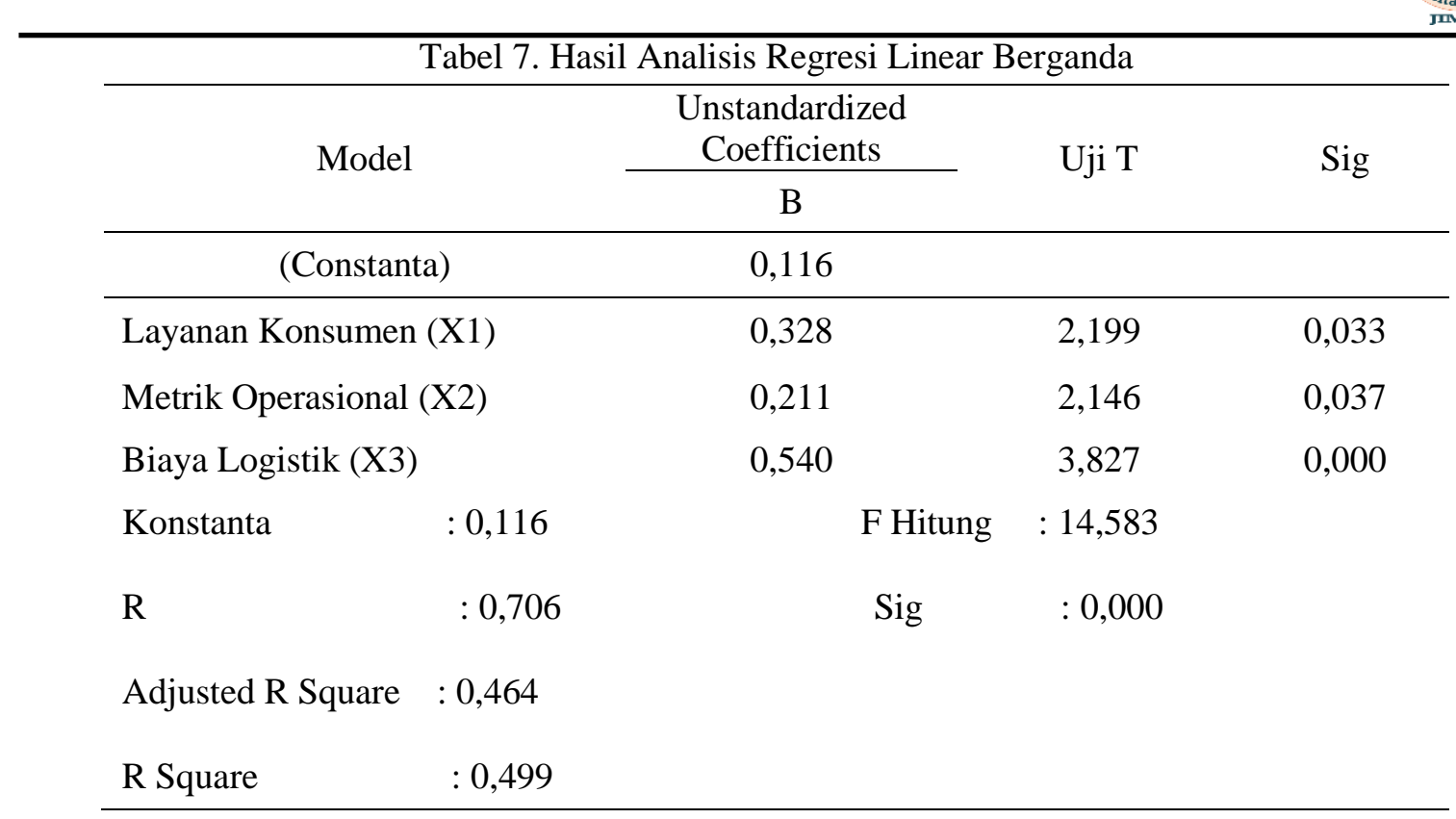

Dari hasil analisis regresi berganda di atas, jika dimasukkan pada model persamaan regresi adalah sebagai berikut:

$$
\begin{gathered}
Y=\alpha+b_{1} X_{1}+b_{2} X_{2}+b_{3} X_{3} \\
Y=0,116+0,328 X_{1}+0,211 X_{2}+0,540 X_{3}
\end{gathered}
$$

Berdasarkan persamaan regresi di atas, dapat diketahui bahwa ketiga variabel tersebut atau variabel bebas (layanan konsumen, metrik operasionaldan biaya logistik) memiliki penjelasan nilai koefisien sebagai berikut :

1. Nilai konstanta $(\alpha)$ memiliki nilai 0,116 , hal ini berarti jika variabel $X_{1}, X_{2}, X_{3}$ di anggap konstan atau tidak mengalami perubahan (bernilai 0) maka kinerja operasional industri rotan di Kota Palu memiliki nilai tetap positif 0,116 .

2. Nilai koefisien regresi variabel layanan kosumen $\left(X_{1}\right)$ adalah postif yaitu sebesar 0,328 . Hal ini menyatakan bahwa jika nilai layanan konsumen meningkat maka kinerja operasional industri rotan juga meningkat.

3. Nilai koefisien regresi variabel metrik operasional $\left(\mathrm{X}_{2}\right)$ adalah positif yaitu sebesar 0,211 . Hal ini menyatakan bahwa jika nilai metrik operasional meningkat, maka akan meningkat juga kinerja operasional industri rotan.

4. Nilai koefisien regresi variabel biaya logistik $\left(\mathrm{X}_{3}\right)$ adalah positif yaitu sebesar 0,540. Hal ini menyatakan bahwa jika nilai biaya logistik meningkat, maka akan meningkatjuga kinerja operasional industri rotan.

5. Nilai koefisien korelasi $(\mathrm{R})$ yaitu sebesar 0,706 . Nilai $R$ berkisar antara 0 sampai 1 , apabila nilai $\mathrm{R}$ mendekati 0 maka hubungan antara variabel semakin rendah. Apabila nilai $\mathrm{R}$ mendekati 1 persen maka hubungan antara variabel semakin tinggi. Nilai pada penelitian ini adalah 0,706 menunjukkan bahwa hubungan antara variabel layanan konsumen, metrik operasional, dan biaya logistik terhadap kinerja operasional adalah mendekati tinggi.

\section{Pengujian Hipotesis}

Untuk mengetahui pengaruh signifikan secara simultan maupun secara parsial dari variabel independen terhadap variabel dependen, maka perlu dilakukan uji F dan Uji t. Hasil dari uji F dan uji t dijelaskan lebih lengkap dibawah ini. 


\section{Hasil Uji Simultan (Uji F)}

Uji simultan dilakukan untuk mengetahui apakah variabel independen atau variabel bebas (layanan konsumen, metrik operasional, dan biaya logistik) berpengaruh secara simultan terhadap variabel dependen atau variabel terikat (kinerja operasional) industri kerajinan rotan di Kota Palu.

Hasil uji F di tampilkan seperti Tabel di bawah ini.

Tabel 8. Hasil Pengujian Secara Simultan (Uji F) ANOVA ${ }^{\text {b }}$

\begin{tabular}{llccccc}
\hline Model & $\begin{array}{c}\text { Sum of } \\
\text { Squares }\end{array}$ & Df & Mean Square & F & Sig. \\
\hline 1 & Regression & 2.921 & 3 & 0.974 & 14.583 & $.000^{\text {a }}$ \\
& Residual & 2.938 & 44 & 0.067 & & \\
& Total & 5.859 & 47 & & & \\
\hline
\end{tabular}

Dari Tabel 8 di atas, hasil pengujian model regresi diperoleh nilai $\mathrm{F}$ hitung sebesar 14.583 dengan signifikansi 0,000 dengan nilai $\alpha$ (batas signifikan) adalah 0,05 . Sehingga dapat diketahui bahwa $0,000<0,05$ maka model analisis regresi ini dinyatakan signifikan. Hal ini menyatakan bahwa H0 ditolak dan dapat disimpulkan bahwa hipotesis menyatakan bahwa kinerja logistik yang terdiri dari layanan konsumen, metrik operasional, dan biaya logistik secara simultan berpengaruh signifikan terhadap kinerja operasional UKM industri rotan di Kota Palu.

\section{Hasil Uji Parsial (Uji t)}

Pengujian ini dilakukan untuk mengetahui seberapa besar pengaruh variabel independen atau variabel bebas (layanan konsumen, metrik operasional, dan biaya logistik) secara parsial berpengaruh signifikan terhadap variabel dependen atau variabel terikat (kinerja operasional). Uji parsial atau uji t ini dilakukan dengan membandingkan nilai sig t dengan taraf signifikan atau $\alpha=0,05$. Uji parsial digunakan sebagai alat untuk menguji hipotesis variabel kinerja logistik yang terdiri dari layanan konsumen, metrik operasioanl dan biaya logistik terhadap variabel kinerja operasional. Hasil uji t atau uji parsial lebih jelasnya dapat dilihat pada penjelasan di bawah ini :

\section{Variabel Layanan Konsumen $\left(X_{I}\right)$}

Dari hasil pengolahan data yang dilakukan, dapat di lihat besar probabilitas signifikan layanan konsumen $\left(\mathrm{X}_{1}\right)$ sebesar $0,033<\alpha 0,05$ maka secara statistik dalam penelitian ini variabel layanan konsumen secara parsial berpengaruh signifikan terhadap kinerja operasional industri kerajinan rotan di Kota Palu.

\section{Variabel Metrik Operasioanl $\left(\mathrm{X}_{2}\right)$}

Berdasarkan hasil pengolahan data yang dilakukan, dapat di lihat besar probabilitas signifikan metrik operasional $\left(\mathrm{X}_{2}\right)$ sebesar $0,037<\alpha 0,05$. Dengan hasil tersebut maka secara statistik dinyatakan bahwa variabel metrik operasional secara parsial berpengaruh signifikan terhadap kinerja operasional industri kerajinan rotan di Kota Palu.

\section{Variabel Biaya Logistik $\left(X_{3}\right)$}

Berdasarkan hasil pengolahan data yang dilakukan, dapat di lihat besar probabilitas signifikan biaya logistik $\left(\mathrm{X}_{3}\right)$ sebesar $0,000<\alpha 0,05$. Dengan hasil tersebut maka secara statistik dinyatakan bahwa variabel biaya logistik secara parsial berpengaruh signifikan terhadap kinerja operasional industri kerajinan rotan di Kota Palu.

\section{Uji Koefisien Determinasi $\left(R^{2}\right)$}

Agar dapat mengetahui seberapa besar kontribusi variabel independen (layanan konsumen, metrik operasional dan biaya logistik) terhadap variabel dependen (kinerja operasional) digunakan nilai dari hasi uji $\mathrm{R}^{2}$. Hasil uji R dijelaskan sebagai berikut: 
Tabel 9. Koefisien Determinasi $\left(\mathrm{R}^{2}\right)$

\begin{tabular}{lrrrr}
\hline Model & R & R Square & \multicolumn{1}{c}{$\begin{array}{c}\text { Adjusted R } \\
\text { Square }\end{array}$} & $\begin{array}{c}\text { Std. Error of the } \\
\text { Estimate }\end{array}$ \\
\hline 1 & $0.706^{\mathrm{a}}$ & 0.499 & 0.464 & 0.258 \\
\hline
\end{tabular}

Dari hasil pengolahan data yang dilakukan dengan menggunakan SPSS di atas, dapat dilihat bahwa nilai $\mathrm{R}$ dan Adjusted $R$ Square masing-masing 0,706 dan 0,464 di jelaskan sebagai berikut:

1. Nilai Adjusted $R$ square atau koefisien determinasi memiliki nilai sebesar 0,464. Nilai tersebut menunjukkan besarnya pengaruh variabel independen secara keseluruhan (simultan) terhadap variabel dependen, sehingga dapat diketahui bahwa secara keseluruhan pengaruh variabel independen terhadap variabel dependen dalam penelitian ini adalah sebesar $46 \%$ atau dapat pula diartikan bahwa $46 \%$ variasi dari variabel kinerja logistik (X) dapat dijelaskan oleh variasi dari masing-masing variabel independennya (layanan konsumen $\left(X_{1)}\right.$ metrik operasional $\left(X_{2}\right)$ dan biaya logistik $\left(\mathrm{X}_{3}\right)$, sedangkan sisanya $54 \%(100 \%$ - 46\%) dijelaskan oleh pengaruh variabelvariabel lain yang tidak disertakan dalam penelitian ini.

2. Koefisien korelasi (R) memiliki nilai sebesar 0,706 yang berarti bahwa variabel yang diteliti yaitu layanan konsumen, metrik operasional dan biaya logistik mempunyai hubungan yang kuat dengan variabel terikatnya sebesar 0,706 atau sebesar $70 \%$.

\section{Pembahasan Hasil Penelitian}

Tujuan pembahasan hasil penelitian untuk mengetahui penjelasan dari variabel bebas (layanan konsumen, metrik operasional, dan biaya logistik) terhadap variabel terikat (kinerja operasional) berpengaruh secara simultan dan parsial. Berikut di bawah ini akan di jelsakan pembahasan hasil penelitian mengenai pengaruh kinerja logistik $(\mathrm{X})$ secara simultan terhadap kinerja operasional $(\mathrm{Y})$, pengaruh layanan konsumen $\left(\mathrm{X}_{1}\right)$ secara parsial terhadap kinerja operasional $(\mathrm{Y})$, pengaruh metrik operasional $\left(\mathrm{X}_{2}\right)$ secara parsial terhadap kinerja operasional $(\mathrm{Y})$ serta pengaruh biaya logistik $\left(\mathrm{X}_{3}\right)$ secara parsial terhadap kinerja operasional (Y) UKM industri rotan di Kota Palu.

\section{Pengaruh Kinerja Logistik (X) Secara Simultan Terhadap Kinerja Operasional (Y) Industri Kerajinan Rotan}

Kinerja logistik dalam penelitian ini secara konsep didukung oleh tiga variabel yaitu layanan konsumen, metrik operasional dan biaya logistik. Variabel tersebut merupakan satu kesatuan yang dapat menunjang kinerja operasional industri kerajinan rotan di Kota Palu.

Dari hasil penelitian diketahui bahwa secara simultan kinerja logistik berpengaruh signifikan terhadap kinerja operasional, hal ini membuktikan bahwa kinerja operasional industri kerajinan rotan di Kota Palu akan meningkat apabila didukung oleh kinerja logistik yang baik juga. Misalnya, kinerja logistik yang baik akan mendukung kelancaran pengiriman bahan baku dan lancarnya pengiriman bahan baku akan menjamin ketersediaan produk pada industri kerajinan rotan.

Menurut Marwan Setiawan, (2013) menyatahkan bahwa terdapat hubungan positif antara kinerja logistik (Customer Service, Operational Metric, and Logistic Cost) terhadap tingkat penjualan dilihat dari nilai $\mathrm{R}$ sebesar 0,311 berarti bahwa hubungan antara kinerja logistik terhadap tingkat penjualan sebesar $31,10 \%$.

\section{Pengaruh Layanan Konsumen $\left(\mathrm{X}_{1}\right)$ Terhadap Kinerja Operasional (Y) Industri Kerajinan Rotan}

Layanan konsumen yang dimaksud dalam penelitian ini merupakan dimensi yang paling penting yang ditawarkan perusahaan kepada para konsumen. Dari hasil uji parsial (uji t), diketahui bahwa layanan konsumen memberikan pengaruh signifikan terhadap kinerja operasional industri kerajinan rotan di Kota Palu.

Kontribusi terbesar yang mempengaruhi layanan konsumen terhadap kinerja operasional diberikan oleh indikator $\mathrm{X}_{1.6}$ layanan pendukung (service support) dengan nilai mean tertinggi dari yang lain yaitu sebesar 4,42. Ini membuktikan bahwa layanan pendukung (service support) seperti hari-hari besar keagamaan para supplier selalu menyediakan stok bahan baku sehingga para pemilik 
usaha mau memesan bahan baku tidak menunggu waktu yang lama. Layanan yang baik dari supplier maupun dari pemilik usaha akan mempengaruhi kelancaran pengiriman bahan baku atau produk jadi, sehingga apabila supplier melakukan pengiriman bahan baku pada industri maka akan menjamin ketersediaan produk saat konsumen melakukan permintaan produk jadi pada industri kerajinan rotan di Kota Palu.

Menurut Marwan Setiawan, (2013) menyatahkan bahwa tidak terdapat hubungan positif antara layanan konsumen terhadap tingkat penjualan dibandingkan dengan variabel metrik operasional dan biaya logistik, sedangkan menurut Audita Nuvriasari Ada pengaruh yang positif dan signifikan antara pengelolaan layanan konsumen terhadap kinerja UKM industri rotan, dimana nilai signifikansi $(\alpha)<$ 0,005 . Pembuktian hipotesis ini mendukung hasil penelitian yang dilakukan oleh Mohamad et al (2014) dimana pengaruh layanan konsumen terhadap kinerja UKM industri rotan memiliki pengaruh yang positif dan signifikan, dimana semakin baik layanan konsumen maka kinerja UKM industri rotan akan semakin baik. Dalam penelitian ini indikator layanan konsumen ditunjukkan melalui: Fokus pada pelanggan inti, Pengetahuan manajemen, dan Pemasaran hubungan. Sedangkan kinerja UKM industri rotan diukur melalui kinerja finansial, loyalitas pelanggan, kepuasan pelanggan, kebertahanan pelanggan, dan kinerja yang diterima. Hasil penelitian ini juga mendukung penelitian yang dilakukan oleh Hisham (2011) yang menunjukkan bahwa terdapat pengaruh yang positif dan signifikan antara layanan konsumen dengan kinerja perusahaan. Layanan konsumen ditunjukkan dari indikator fokus pada pelanggan inti, efisiensi organisasi dan manajemen pengetahuan pelanggan.

\section{Pengaruh Metrik Operasional $\left(\mathbf{X}_{2}\right)$ Terhadap Kinerja Operasional (Y) Industri Kerajinan Rotan}

Metrik operasional merupakan kegiatan operasional yang dilakukan oleh industri rotan yang berkaitan dengan kinerja logistik. Indikator dari dimensi ini adalah:

1. Jumlah barang yang disimpan

2. Pemeliharaan stok barang

3. Ketepatan dalam pemesanan barang

4. Ketersediaan transportasi

5. Lokasi perusahaan yang strategis

6. Warehouse (ketersediaan gudang)

7. Lokasi fasilitas pergudangan

8. Tata letak gudang

9. Kepemilikan gudang

Dari hasil uji parsial (uji t), diketahui bahwa metrik operasional memberikan pengaruh signifikan terhadap kinerja operasional industri kerajinan rotan di Kota Palu. Kontribusi terbesar yang mempengaruhi metrik operasional terhadap kinerja operasional diberikan oleh indikator $\mathrm{X}_{2.6}$ dengan nilai mean yang paling tinggi yaitu sebesar 4,63 karena ketersediaan gudang (warehouse) yang memadai dapat membantu ketersediaan bahan baku apabila diperlukan segera dan ketersediaan barang jadi di tempat usaha. Dengan adanya gudang akan membantu kinerja operasional suatu industri, dan gudang juga merupakan tempat penyimpanan bahan baku apabila diperlukan. Menurut Marwan Setiawan, (2013) menyatahkan bahwa terdapat hubungan postif antara kinerja logistik (operational metric) terhadap tingkat penjualan dilihat dari hasil pengolahan data melalui SPSS dapat dilihat taraf signifikansinya sebesar 0,046 .

\section{Pengaruh Biaya Logistik $\left(\mathbf{X}_{3}\right)$ terhadap Kinerja Operasional (Y) Industri Kerajinan Rotan.}

Biaya logistik memiliki peran yang besar dalam menunjang kinerja operasional suatu industri, oleh karena itu biaya tersebut harus dikelola semaksimal mungkin agar tidak terjadi kerugian bagi sebuah usaha. Indikator yang digunakan dalam dimensi ini meliputi Biaya pemesanan, biaya pemeliharaan barang, biaya pengadaan fasilitas gudang, biaya pengemasan, biaya penyimpanan, biaya kerusakan barang, biaya pengiriman, biaya sewa transportasi dan biaya perantara (broker). Dari hasil uji parsial (uji t) menyatakan bahwa biaya logistik memberikan pengaruh signifikan terhadap kinerja operasional industri kerajinan rotan di Kota Palu.

Kontribusi yang paling besar diberikan oleh biaya logistik terhadap kinerja operasional adalah indikator $\mathrm{X}_{3.8}$ dengan nilai mean sebesar 4,69 , karena biaya transportasi yang cukup tinggi akan 
mempengaruhi kinerja sebuah industri. Apabila biaya yang dikeluarkan semakin tinggi maka pendapatan akan berkurang sebaliknya apabila biaya yang dikeluarkan semakin rendah maka pendapatan akan bertambah. Hal ini menunjukkan bahwa transportasi memiliki peran penting saat mengantarkan bahan baku ke industri rotan. Dari hasil penelitian diketahui bahwa bahan baku rotan diperoleh dari luar Kota Palu sihingga memerlukan transportasi yang mengantarkan bahan baku dari tempat pemesanan sampai ke industri-industri rotan yang ada di Kota Palu. Marwan Setiawan, (2013) menyatahkan bahwa terdapat hubungan postif antara kinerja logistik (logistics cost) terhadap tingkat penjualan, di lihat dari hasil pengolahan data melalui SPSS dapat dilihat taraf signifikansinya sebesar 0,029 .

\section{KESIMPULAN DAN SARAN}

\section{Kesimpulan}

Berdasarkan hasil dan pembahasan yang telah dilakukan pada bab sebelumnya, dapat diambil kesimpulan sebagai berikut:

1. Kinerja logistik yang terdiri dari variabel layanan konsumen $\left(\mathrm{X}_{1}\right)$, metrik operasional $\left(\mathrm{X}_{2}\right)$, dan biaya logistik $\left(\mathrm{X}_{3}\right)$ secara simultan berpengaruh signifikan terhadap kinerja operasional pada industri kerajinan rotan rotan di Kota Palu.

2. Variabel layanan konsumen $\left(\mathrm{X}_{1}\right)$ berpengaruh signifikan terhadap kinerja operasional industri kerajinan rotan di Kota Palu.

3. Variabel metrik operasional $\left(\mathrm{X}_{2}\right)$ berpengaruh signifikan terhadap kinerja operasional industri kerajinan rotan di Kota Palu.

4. Variabel biaya logistik $\left(\mathrm{X}_{3}\right)$ berpengaruh signifikan terhadap kinerja operasional industri kerajinan rotan di Kota Palu.

\section{Saran}

Berdasarkan pembahasan dan kesimpulan yang ada, saran-saran yang dapat di berikan penulis adalah sebagai berikut:

1. Untuk pemilik UKM industri rotan yang ada di Kota Palu, harus lebih meningkatkan lagi kinerja dari variabel layanan konsumen, metrik operasional dan biaya logistik agar nantinya dapat mempengaruhi kinerja operasionalnya. Layanan konsumen yang baik dan metrik operasional yang mendukung serta biaya logistik yang dikeluarkan rendah akan membantu kinerja dari UKM industri rotan itu sendiri.

2. Untuk penelitian selanjutnya, diharapkan dapat menambah variabel penelitian yang dapat mempengaruhi kinerja operasional industri kerajinan rotan di Kota Palu, agar hasil penelitiannya dapat memberikan kontribusi yang lebih untuk pihak-pihak yang bersangkutan.

\section{REFERENSI}

Anderson, D. L., Britt, F. E. \& Favre, D. J. (1997). The seven Principles of Supply Chain Management. Supply chain Management Review, 1, 31-43.

Chandra, A. (2013). Analisis Kinerja Distribusi Logistik Pada Pasokan Barang Dari Pusat Distribusi Ke Gerai Indomaret di Kota Semarang. Jurnal Institusional Repository. http://eprints.undip.ac.id/40234/. Diakses 21 November 2016. Hal. 15-24.

Creswell, J. W. (2012). Research Design; Qualitative, Quantitative, And Mixed Method Approaches. Sage, Los Angeles.

Ghozali, I. (2006). Aplikasi Analisis Multivariate Dengan Program Spss. Semarang: Badan Penerbit Undip.

Hisham, SS., (2011), Customer Relationship Management And Its Relationship To The Marketing

Performance, International Journal Of Business And Social Science, Vol. 2, No. 10.

Lambert, D. M. \& Stock, J. R. (2001). Strategic Logistic Manajement, Fourth Edition. New York USA: Mc Graw Hill.

Schramm-Klein, H. \& Morschett, D. (2006). The Relationship Between Marketing Performance, Logistics Performance And Company Performance For Retail Companies. International Review Of Retail, Distribution And Consumer Research, 16(2), 277-96. 
Setawan Marwan \& H, Suryadi. (2013). The Impact Of Logistik Performance On The Sales Level. 2013. International Conference On Information System For Business Competitiveness (ICISBC)

Shang, K. \& Marlow, P. B. (2005), Logistics Capability and Performance In Taiwan's Major Manufacturing Firms. Transportation Research Part E, 41(3), 217-34.

Siagian, Y. M. (2005). Aplikasi Supply Chain Management Dalam Dunia Bisnis. Jakarta: PT. Gramedia Widiasarana Indonesia.

Simchi-Levi, D., Kaminsky, P. \& Simchi-Levi, E. (2003). Designing And Managing The Supply Chain: Concept, Strategies And Case Studies, 2nd ed. New York: McGraw-Hill.

Sinaga. (1986). Kajian Potensi Dan Peluang Ekspor Rotan Indonesia. Jurnal Penelitian Hasil Hutan, 8,49-54 